\title{
CEREBRAL TRYPANOSOMIASIS AND AIDS
}

\author{
Apio Claudio Martins Antunes ${ }^{1}$, Felipe Martins de Lima Cecchini ${ }^{2}$, \\ Fernando von Bock Bolli2, Patricia Polanczyk de Oliveira ${ }^{2}$, \\ Ricardo Gurgel Rebouças², Thais Lampert Monte ${ }^{3}$, Daniele Fricke ${ }^{4}$
}

\begin{abstract}
A 36 year-old black female, complaining of headache of one month's duration presented with nausea, vomiting, somnolence, short memory problems, loss of weight, and no fever history. Smoker, intravenous drugs abuser, promiscuous lifestyle. Physical examination: left homonimous hemianopsia, left hemiparesis, no papilledema, diffuse hyperreflexia, slowness of movements. Brain CT scan: tumor-like lesion in the splenium of the corpus calosum, measuring $3.5 \times 1.4 \mathrm{~cm}$, with heterogeneous enhancing pattern, sugesting a primary CNS tumor. Due to the possibility of CNS infection, a lumbar puncture disclosed an opening pressure of $380 \mathrm{mmH}_{2} 0 ; 11$ white cells (lymphocytes); glucose $18 \mathrm{mg} / \mathrm{dl}$ (serum glucose $73 \mathrm{mg} / \mathrm{dl}$ ); proteins $139 \mathrm{mg} / \mathrm{dl}$; presence of Trypanosoma parasites. Serum Elisa-HIV tests turned out to be positive. Treatment with benznidazole dramatically improved clinical and radiographic picture, but the patient died 6 weeks later because of respiratory failure. T. cruzi infection of the CNS is a rare disease, but we have an increasing number of cases in HIV immunecompromised patients. Diagnosis by direct observation of CSF is uncommon, and most of the cases are diagnosed by pathological examination. It is a highly lethal disease, even when properly diagnosed and treated. This article intends to include cerebral trypanosomiasis in the differential diagnosis of intracranial space-occupying lesions, especially in immunecompromised patients from endemic regions.
\end{abstract}

KEY WORDS: trypanosomiasis, trypanosoma cruzi, AIDS, benznidazole, nifurtimox.

\section{Tripanossomíase cerebral e SIDA}

RESUMO - Uma mulher negra de 36 anos, procurou a emergência do hospital com quadro de cefaléia holocraniana há 1 mês. Evoluiu com náuseas e vômitos, sonolência e diminuição da memória, associadas a emagrecimento, sem história de febre. Tabagista, usuária de drogas endovenosas, história de promiscuidade sexual. Exame físico: hemianopsia homômima esquerda, hemiparesia esquerda, sem papiledema, hiperreflexia profunda difusa e lentificação dos movimentos. A TC de crânio mostou lesão expansiva no esplênio do corpo caloso com 3,5 x 1,4 cm, com impregnação heterogênea pelo contraste, sugestiva de tumor primário do SNC. Por causa da possibilidade de neuroinfecção, foi realizada uma punção lombar que revelou pressão de abertura de $380 \mathrm{mmH}_{2} \mathrm{O} ; 11$ leucócitos (mononucleares), glicose $18 \mathrm{mg} / \mathrm{dl}$ (glicemia 73mg/dl), proteínas $139 \mathrm{mg} / \mathrm{dl}$, presença de parasitas com características de Trypanossoma. Testes para HIV foram reagentes. Iniciado tratamento com benzonidazol, a paciente apresentou melhora neurológica e tomográfica. Faleceu 6 semanas após, por insuficiência respiratória. A infecção por T. cruzi no SNC é entidade rara, observando-se número crescente de casos em pacientes imunocomprometidos por infecção pelo HIV. O diagnóstico por exame direto no líquor é incomum, em sua maioria sendo os casos diagnosticados por exame anátomo-patológico (biópsia ou necrópsia). É doença de alta letalidade, mesmo com diagnóstico e tratamento adequados. É necesário incluir a tripanossomíase cerebral no diagnóstico diferencial das patologias expansivas intracranianas, principalmente em pacientes imunodeprimidos e provenientes de áreas endêmicas.

PALAVRAS-CHAVE: tripanossomíase, tripanosoma cruzi, SIDA, benzonidazol, nifurtimox.

The problem of a patient with an intracranial mass lesion and acquired immunodeficiency syndrome (AIDS) imposes an enormous list of diagnostic possibilities. The management of this particular situation is sometimes a real challenge. Cases of patients pre- viously infected with T. cruzi presenting with chagasic meningoencephalitis have been reported since 1990'. We present a patient with AIDS and intracranial mass whose cerebral spinal fluid (CSF) examination showed Trypanosoma cruzi.

\footnotetext{
Hospital de Clínicas de Porto Alegre, Porto Alegre RS, Brasil; ${ }^{1}$ Professor-Adjunto de Neurocirurgia, Doutor, Faculdade de Medicina da Universidade Federal do Rio Gande do Sul (UFRGS); ${ }^{2}$ Residente em Neurocirurgia; ${ }^{3}$ Médica Neurologista, Mestre em Clínica Médica, UFRGS, ${ }^{4}$ Residente em Neurologia.
}

Received 13 March 2002. received in final form 13 April 2002. Accepted 20 April 2002. 


\section{CASE}

A 36-year-old black female was admitted complaining of severe headache non-amenable to common analgesics, and progressive left hemiparesis for one month. She also had a history of general malaise, vomitting and significant weight loss (10 kg in two months). She had no allergies and was not using medication on chronic basis, but there was history of smoking and intravenous drug abuse. She had a promiscuous life, with nine pregnancies and one abortion, and had been submitted to blood transfusion. The patient was oriented, but mildly somnolent, vital signs were stable, and she had disseminated hypocromic skin lesions. Neurologic examination disclosed a left homonimous hemianopsia, mild left hemiparesis, diffuse hyperreflexia and normal fundoscopy. Her movements were slow with normal coordination. She was unable to walk without someone's help.

Blood tests showed leukopenia (2730 leukocytes, 6\% lymphocytes), hematocrit was $27.42 \%$. HIV tests were performed (ELISA). Brain CT disclosed a contrast-enhancing tumor-like lesion in the splenium of the corpus calosum, measuring $3.5 \times 1.4 \mathrm{~cm}$, with heterogeneous enhancing pattern (Fig 1).

Due to the possibility of central nervous system (CNS) infection, the patient was then submitted to a lumbar puncture. CSF was clear, pressure was $380 \mathrm{mmH}_{2} \mathrm{O}$, and the examination showed 11 white cells $/ \mathrm{mm}^{3}$ (lymphocytes) glucose $18 \mathrm{mg} / \mathrm{dL}$ (blood glucose $73 \mathrm{mg} / \mathrm{dL}$ ), proteins 139 $\mathrm{mg} / \mathrm{dl}$ and the presence of parasites with the characteristics of Trypanosomatidae family (Fig 2). HIV blood tests were positive, with a CD4 count of $8 / \mathrm{mm}^{3}$. Serologic tests for Chagas' disease were all positive. No sign of chronic infection was found. Treatment with benznidazole $5 \mathrm{mg} / \mathrm{kg}$ was initiated. The patient showed clinical and radiographic improvement (Fig 3), and a new lumbar puncture performed 20 days later disclosed clear CSF with no parasites. In spite of the good response to phamacological therapy with benznidazole, the patient died 40 days later due to pulmonary complications.

\section{DISCUSSION}

American trypanosomiasis affects $16-18$ million people and some 100 million, i.e. about $25 \%$ of the population of Latin America, is at risk of acquiring Chagas' disease ${ }^{2}$. The disease exists only in the American Continent, and is caused by Trypanosoma cruzi, a flagellated protozoan parasite, transmitted to humans by haematophagous triatomine insects. Transmission of T. cruzi may also occur through blood transfusion, especially in individuals who receive repeated transfusions ${ }^{3}$.

In the acute phase, the disease is usually silent. Only $35 \%$ of patients show symptoms ${ }^{4}$ like: fever, general malaise, headache, edema, lymphadenopathy and hepatosplenomegaly 5 . Myocarditis, mos-

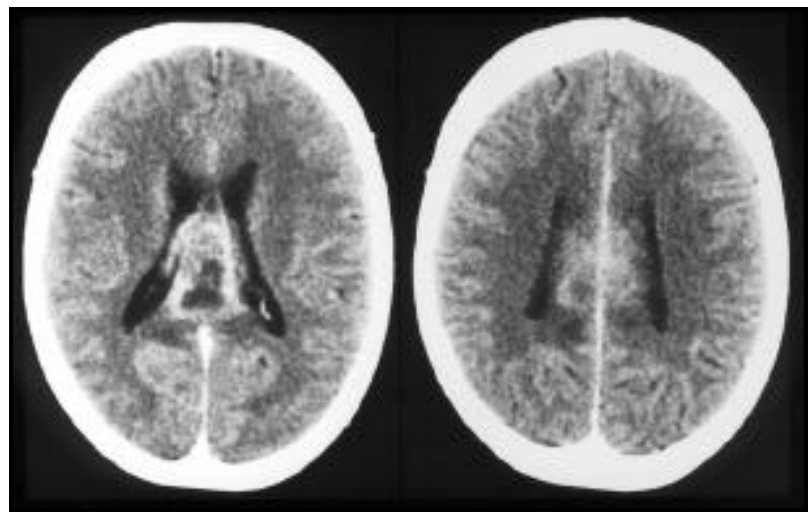

Fig 1. CT scan: lesion in the splenium of the corpus calosum with heterogenous enhancing pattern.

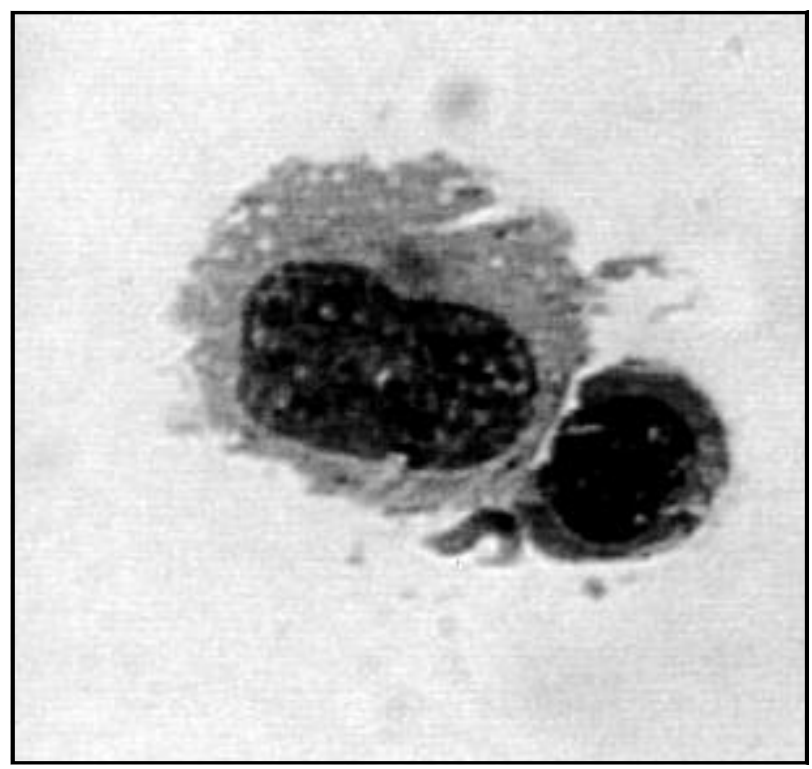

Fig 2. CSF examination: T. cruzi parasites indentified on direct examination.

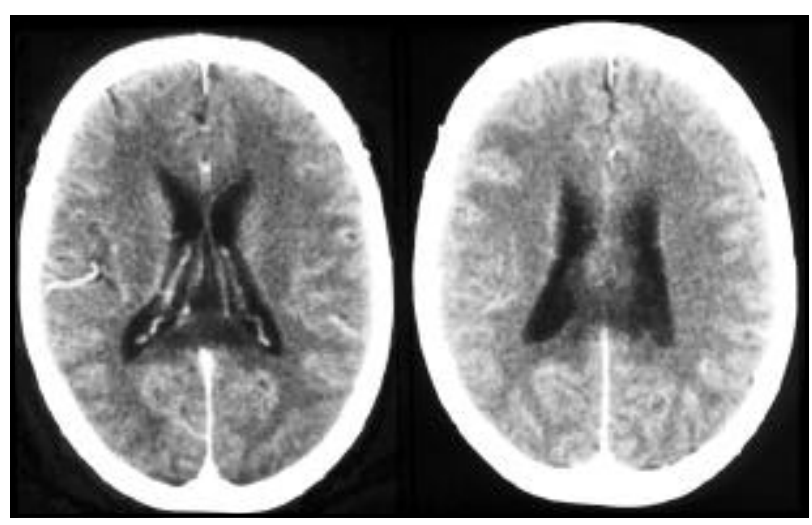

Fig 3. CT scan (after drug treatment): normal appearance after contrast injection. 
Table 1. Published cases of Trypanosoma cruzi meningoencephalitis in AIDS patients. Modified from Veronesi ${ }^{8}$.

\begin{tabular}{|c|c|c|c|c|c|c|c|c|}
\hline \multicolumn{9}{|c|}{ Published Cases } \\
\hline \multirow[t]{2}{*}{ Case } & \multirow[t]{2}{*}{ Age/Sex } & \multirow[t]{2}{*}{$\mathrm{CD} 4 / \mathrm{mm}^{3}$} & \multirow[t]{2}{*}{ Serology } & \multicolumn{2}{|c|}{ T. cruzi } & \multirow[t]{2}{*}{ Treatment } & \multirow[t]{2}{*}{ Survival } & \multirow[t]{2}{*}{ Reference } \\
\hline & & & & Blood & $d C S F$ & & & \\
\hline 1 & 19/M & NR & + & NR & NR & Surgery, Nifurtimox & More than 3 months & Del Castillo et al., $1990^{1}$ \\
\hline 2 & $37 / M$ & NR & + & $\mathrm{N}$ & $\mathrm{N}$ & $\mathrm{N}$ & $\mathrm{N}$ & Ferreira et al., 1992 \\
\hline 3 & $26 / F$ & NR & + & NR & $\mathrm{Y}$ & Benznidazole & 2 months & Gallo et al., $1992^{12}$ \\
\hline 4 & $32 / \mathrm{M}$ & 45 & + & $\mathrm{N}$ & NR & $\mathrm{N}$ & $\mathrm{N}$ & Gluckstein et al., $1992^{13}$ \\
\hline 5 & $31 / \mathrm{M}$ & 35 & + & $x$ & NR & Benznidazole & More than 6 months & Oddó et al., $1992^{14}$ \\
\hline 6 & $40 / \mathrm{M}$ & NR & + & $x$ & NR & $\mathrm{N}$ & $\mathrm{N}$ & Oddó et al., $1992^{14}$ \\
\hline 7 & $40 / \mathrm{M}$ & NR & + & NR & $\mathrm{Y}$ & $\mathrm{N}$ & $\mathrm{N}$ & Rosemberg et al., $1992^{9}$ \\
\hline 8 & $52 / \mathrm{M}$ & NR & + & NR & NR & $\mathrm{N}$ & $\mathrm{N}$ & Rocha et al., $1993^{15}$ \\
\hline 9 & $33 / \mathrm{M}$ & 382 & + & Y & $\mathrm{Y}$ & Benznidazole & & Nishioka et al., $1993^{16}$ \\
\hline 10 & $48 / F$ & NR & + & $\mathrm{Y}$ & $\mathrm{Y}$ & Benznidazole & & Metze \& Maciel, $1993^{17}$ \\
\hline 11 & $47 / M$ & NR & + & Y & $\mathrm{Y}$ & Benznidazole & About 1 month & Pimentel et al., $1996^{5}$ \\
\hline 12 & $36 / F$ & 8 & + & Y & $\mathrm{Y}$ & Benznidazole & 6 weeks & This paper \\
\hline
\end{tabular}

tly seen as an EKG alteration, may happen. Sometimes the clinical presentation takes the form of a meningoencephalitis, a severe condition that occurs specially in infants and children younger than three yearsold, commonly associated with acute myocarditis. Although CNS involvement is rare, the presence of the parasite in the CNS has been proved in 1953 by Freitas et al. ${ }^{6}$. Hoff et al. ${ }^{7}$ showed that $72 \%$ of patients investigated in the acute phase had T. cruzi in the CSF.

The chronic phase has three main presentations: (a) indeterminate, (b) cardiac and (c) digestive ${ }^{8}$. The indeterminate type is the most common one: the patient has positive test for Chagas' disease but is asymptomatic. Progressive deterioration of the myocardium leading to cardiomegaly and cardiac failure is the hallmark of the cardiac form and involvement of the bowel and esophagus is what characterizes the digestive form (megacolon and megaesophagus) and is caused by a loss of ganglion cells of the autonomic nervous system in the gut ${ }^{9}$.

The acquired immunodeficiency syndrome has changed the profile of many diseases in the past two decades and Chagas' disease is no exception to the rule. Until 1969, reactivation of chronic Chagas' disease had been recorded only experimentally, when a case of a patient with lymphatic leukemia was reported $^{10}$ afterwards. Reactivation due to AIDS has been reported since $1990^{1}$. The disease tends to present as a severe form of meningoencephalitis, myocardi- tis, or both: it is a highly lethal disease and only a few cases of cure have been reported.

Chagasic meningoencephalitis may be the first presentation of a patient with AIDS. Some patients are found to have low CD4 counts, as demonstrated by Pagano et al. in the analysis of 8 cases (CD4 counts ranging from 126 to $63 \mathrm{cell} / \mathrm{mm} 3) 11$. Imaging of patients with chagasic meningoencephalitis usually presents as a cerebral mass, often called cerebral tumor-like American Trypanosomiasis. Ring and nodular enhancing patterns are the most frequent nonspecific findings, and a differential diagnosis with toxoplasmosis or lymphoma are highly suggested. The lesions appear mostly in the supratentorial white matter ${ }^{9}$, but masses have been reported everywhere in the CNS, including infratentorial region and basal ganglia. The serological tests for Chagas' disease are usually positive, but may be negative and insufficient for the diagnosis, which is made by identification of the parasite in the CSF or more frequently by histological examination of the brain tissue. There are no sufficient data to evaluate the sensitivity of the CSF examination. When the disease is strongly suspected on clinical grounds and when appropriate tests fail to stablish the etiology, a brain biopsy shoud be performed without delay.

There is usually an inflamatory process and neuronal damage $\mathrm{e}^{10}$. Microglial nodules and, less frequently, perivascular mononuclear cuffings are the main 
pathologic findings. In several cases the lesions have a necrotic character. Parasites are seen either in glial cells, macrophages and neurons or may be free in the parenchyma, where they tend to form pseudocysts. Observation of the coexistence of nuclei and kinetoplasts shows the presence of the intracellular amastigote form of the prasasite.

Reactivation of chronic Chagas' disease due to AIDS is uncommon and there have been a few reports since 1990 (Table 1).

Specific treatment has been based on three options: benznidazole ( $5 \mathrm{mg} / \mathrm{kg} /$ day for 60 days), or nifurtimox ( 8 to $10 \mathrm{mg} / \mathrm{kg} /$ day for 120 days in four divided doses; 15 to $20 \mathrm{mg} / \mathrm{kg} /$ day in four divided doses for children 1 to 10 years old). Nifurtimox is effective in treatment of acute Chagas' disease, reducing its severity, but ineffective in the chronic stages of the disease ${ }^{18}$. When therapy is complete, over $80 \%$ of patients are cured.

In conclusion, cerebral trypanosomiasis must be included in the diferential diagnosis of the intracranial lesions in an immunosupressed patient, especially if the patient comes from an endemic area.

\section{REFERENCES}

1. Del Castillo M, Mendoza G, Oviedo J, et al. AIDS and Chagas' disease with central nervous system tumor-like lesion. Am J Med 1990;88:693-694.

2. World Health Organization. Control of Chagas' disease: report of the WHO Expert Committee. Weekly Epidemiological Record, No. 1/2, 3/10 January 1997.

3. Leiguarda R, Roncoroni A, Taratuto AL, et al. Acute CNS infection by Trypanosoma cruzi (Chagas' disease) in immunosuppressed patients. Neurology 1990;40:850-851.

4. Teixeira, MGL. C. Doença de Chagas: estudos da forma aguda inaparente. Tese, Universidade Federal do Rio de Janeiro, 1977.
5. Pimentel PCA, Handfas BW, Carmignani M. Trypanosoma cruzi meningoencephalitis in AIDS mimicking cerebral metastase. Arq Neuropsiquiatr 1996;54:102-106.

6. Pedreira de Freitas JL, Lion MF, Tartari JTA. Resultados de umm investigação sobre moléstia de Chagas realizada no município de Marília e outros, com estudo de dois casos agudos da doença. Rev Hosp Clin São Paulo 1953;8:81-92

7. Hoff R, Teixeira RS, Carvalho JS, Mott KE. Trypanosoma cruzi in the cerebrospinal fluid during the acute stage of Chagas's disease. N Engl J Med 1978; 298: 604-606.

8. Ferreira MS, Lopes ER, Chapadeiro E, Dias JCP, Ostermayer AL. Doença de Chagas. In Veronesi R., Focaccia R (eds). Tratado de Infectologia. São Paulo: Atheneu, 1996:1175-1213.

9. Rosemberg S, Chaves CJ, Higushi ML, et al. Fatal meningoencephalitis cause by a reactivation of Trypanosoma cruzi infection in a patient with Sida. Neurology, 1992;42:640-642.

10. Spina-França A, Mattosinho-França LC. American trypanosomiasis (Chagas' disease). In Vinken PJ, Bruyn GW (eds). Handbook of clinical neurology, vol 35: infections of the nervous system. Amsterdam: Elsevier/North Holland, 1978:85-114.

11. Pagano MA, Segura MJ, Di Lorenzo GA, et al. Cerebral tumor-like American trypanosomiasis in acquired immunodeficiency syndrome. Ann Neurol 1999:45:403-6.

12. Tracy JW, Webster LT, Drugs used in the chemotherapy of protozoal infections: trypanosomiasis, leishmaniasis, amebiasis, giardiasis, trichomoniasis and other protozoal infections. In Gilman GA. Goodman \& Gilman's the pharmacological basis of therapeutics. 9.Ed, New York: McGraw-Hill,1996:998-999

13. Gallo P, Fabião OM Neto, Suarez JMM, Borba RP. Acute central nervous system infection by Trypanosoma cruzi and AIDS. Arq Neuropsiquiatr 1992;50:375-377.

14. Gluckstein D, Ciferri F, Ruskin J. Chagas' disease: another cause of cerebral mass in the acquired immunodeficiency syndrome. Am J Med 1992;92:429-432.

15. Oddó D, Casanova M, Acuña G, et al. Acute Chagas disease (Trypanosomiasis americana) in acquired immunodeficiency syndrome: report of two cases. Human Pathol 1992;23:41-44.

16. Rocha A, Ferreira MS, Nishikosha SA, et al. Trypanosoma cruzi meningoencephalitis and myocarditis in a patient with acquired immunodeficiency syndrome. Rev Inst Med Trop São Paulo 1993;35:205-208.

17. Nishioka AS, Ferreira MS, Rocha A, et al. Reactivation of Chagas disease successfully treated with benznidazole in a patient with acquired immunodeficiency syndrome. Memórias do Instituto Oswaldo Cruz 1993;88:493-496.

18. Metze K, Maciel JÁ Jr. AIDS and Chagas disease. Neurology 1993;43:447-448. 